\title{
DOWN PAYMENT (DP) NOL RUPIAH DALAM KEPEMILIKAN RUMAH MENURUT HUKUM POSITIF DI INDONESIA
}

\author{
Oleh: Hulman Panjaitan \\ hulman234@yahoo.com \\ Universitas Kristen Indonesia, Jakarta, Indonesia
}

\begin{abstract}
In accordance with the provisions of the positive law in force, the ownership or acquisition of land with a "DP Nol Rupiah" or without Down Payment is possible and legal according to the agreement of the parties which in practice is mostly done individually, but if the buying and selling activities, however, if the sale and purchase of the house is done through a business entity, then according to the rules in effect the down payment or down payment is a must. It is time for the government to formulate a policy as the realization of the government's rights and guarantees for the provision of decent and healthy housing that can be affordable by all levels of society.
\end{abstract}

Keywords: without down payment; legal according; purchase of the house; formulate a policy .

\section{Pendahuluan}

Kepemilikan rumah merupakan salah satu kebutuhan dasar manusia selain sandang dan pangan. Selain berfungsi sebagai pelindung terhadap segala gangguan alam dan cuaca maupun makhluk hidup lain, keberadaan rumah juga mempunyai multi fungsi sebagai pusat pendidikan keluarga, tempat membina hubungan kasih dan persaudaran.

Berdasarkan hierarchy of need sebagaimana dikemukakan Maslow, kebutuhan akan rumah dapat didekati sebagai : ${ }^{1}$

- Phsyiological needs (kebutuhan akan makan dan minum), merupakan kebutuhan biologis yang hamper sma untuk setiap orang, yang juga merupakan kebutuhan terpenting selain rumah, sandang dan pangan juga termasuk dalam tahap ini.

- Safety or security needs (kebutuhan akan keamanan), merupakan tempatberlindung bagi penghuni dari gangguan manusia dan lingkungan yang tidak diinginkan.

- Social or affiliation needs (kebutuhan berinteraksi), sebagai tempat untuk berinteraksi dengan keluarga dan teman.

\footnotetext{
1 Badan Pembinaan Hukum Nasional Kementerian Hukum dan HAM RI, Analisis Dan Evaluasi Peraturan Perundang-Undangan Tentang Perumahan Rakyat, Jakarta, 2015, halaman 21.
}

- Self actualization needs (kebutuhan akan ekspresi diri), rumah bukan hanya sebagai tempat tinggal, tetapi menjadi tempat untuk mengakutalisasikan diri.

Bagaimana pentingya kepemilikan rumah bagi setiap orang, hal ini mendapat tempat dalam konstitusi Republik Indonesia melalui Pasal $28 \mathrm{H}$ ayat (1) yang menentukan bahwa setiap orang berhak hidup sejahtera, lahir dan batin, bertempat tinggal dan mendapatkan lingkungan hidup yang baik dan sehat. Hal ini merupakan abstraksi dari tujuan Negara yang tercantum dalam Pembukaan UUD Tahun 1945 "untuk melindungi segenap bangsa Indonesia”.Salah satu bentuknya adalah pemberian dan penyelenggaraan perumahan untuk memenuhi kebutuhan dasar warga Negara bagi peningkatan dan pemerataan kesejahteraan rakyat.

Realisasi lebih lanjut dari pengaturan tentang hak dan kewajiban rakyat dengan pemerintah sebagaimana diamanatkan dalam UUD Tahun 1945 bidang perumahan sebagaimana diuraikan diatas adalah UU No. 1 Tahun 2011 tentang Perumahan dan Kawasan Permukiman, Lembara Negara Republik Indonesia Tahun 2011 Nomor 7, Tambahan Lembaran Negara Republik Indonesia Nomor 5188 yang mengantikan UU No. 4 Tahun 1992, Lembaran Negara Republik Indonesia Tahun 1992 Nomor 23, Tambahan Lembaran 
Negara Republik Indonesia Nomor 3469. Negara sebagai regulator sekaligus eksekutor bertanggung jawab dalam menyediakan dan memberikan kemudahan perolehan rumah bagi masyarakat.Pasal 19 UU No. 1 Tahun 2011 menentukan bahwa pemenuhan hak setiap warga Negara untuk memeiliki rumah dijamin pemerintah.

Sebagaimana diuraikan diatas, kepemilikan rumah sebagai salah satu kebutuhan dasar dan hak setiap orang yang dijamin konstitusi harus dapat dimiliki oleh setiap orang, tidak saja mereka yang berpenghasilan menengah ke atas, tetapi oleh seluruh rakyat Indonesia. Pertumbuhan dan pembangunan wilayah yang kurang memeprhatikan keseimbangan kepentingan masyarakat berpenghasilan rendah telah mengakibatkan kesulitan masyarakat untuk memperoleh rumah yang layak dan terjangkau.

Sampai akhir Februari 2013, Indonesia telah mengalami backlog (angka kekurangan perumahan) hingga 17,6 juta unit rumah. Yang paling banyak mengalamai hambatan kepemilikan rumah adalah masyarakat menengah ke bawah. ${ }^{2}$ Berdasarkan data Badan Pusat Statistik, backlog perumahan di Propinsi DKI Jakarta mencapai kurang lebih 275.000 unit rumah dengan proyeksi kebutuhan rumah (2011-2015) adalah kurang lebih 70.000 unit rumah per tahun. ${ }^{3}$ Permasalahan backlog yang besar ini diperparah dengan makin mahalnya harga tanah dan semakin terbatasnya tanah di daerah perkotaan. ${ }^{4}$

Besarnya backlog perumahan dI DKI Jakarta ternyata cepat ditangkap oleh salah satu calon Gubernur DKI Jakarta pada Pilkada Tahun 2017, Anis Baswedan dan Sandiaga Uno dan karenanya dijadikannya sebagai salah satu program unggulan, yaitu dengan menawarkan pembelian rumah dengan Down Payment (DP) Nol Rupiah. Secara gamblang dan sederhana, tampaknya dengan DP Nol Rupiah yang ditawarkan sangat menggiurkan dan sangat menjanjikan, khususnya bagi masyarakat DKI Jakarta yang berpenghasilan menengah ke bawah. ${ }^{5}$

2 Ibid, halaman 3.

3 Saat ini sudah mencapai 302.000 unit rumah

4 Ibid, halaman 114-115.

5 Secara kuantitatif belum ada rumusan atau kriteria untuk golongan masyarakat berrpenghasilan menengah ke bawah. Peraturan Gubernur DKI Jakarta No. 27 Tahun 2009 tentang Pembangunan Rumah Susun Sederhana merumuskan Masyarakat Berpenghasilan Rendah (MBR) adalah sebagai kelompok sasaran keluarga/
Anadi kata quod non, dibalik itu sesungguhnya terdapat sejumlah persyaratan yang tidak mudah dipenuhi warga DKI Jakarta sebagai peserta DP Nol Rupiah tersebut, yaitu diantaranya adalah mereka yang mempunyai pengasilan rendah minimal $\mathrm{Rp}$. 7.000.000,- (tujuh juta rupiah) setiap bulan dan mempunyai kemampuan menabung minimal $\mathrm{Rp}$. 2.300.000,- (dua juta tiga rtaus ribu rupiah) per bulan selama 6 (enam) bulan. Gaji atau penghasilan Rp. 7.000.000,- (tujuh juta rupiah) perbulan sesungguhnya bukan penghasilan rendah lagi. Dan bahkan secara tegas Sandiaga Uno, wakil Gubernur DKI Jakarta pada tanggal 6 Nopember 2017 sebagaimana dikutif Bisnis. com, mengemukakan bahwa konsep pembelian rumah dengan DP Nol Rupiah ditujukan kepada penduduk yang memiliki pendapatan Rp. 7-10 juta rupiah. Lebih lanjut dikemukakan, jika dilihat penghasilannya memungkinkan tapi daya untuk menabung tidak ada, keluarga berpenghasilan sekitar Rp. 7.000.000,tidak dapat menikmati program tersebut. Kalau dia pendapatannya Rp. 7.000.000,- tapi penngeluarannya Rp. 6.900.000,- nggak akan bisa partisipasi.

Dalam rangka itulah, tulisan ini bermaksud untuk menelaah dan membahas bagaimana pengaturan DP Nol Rupiah tersebyr dalam persfektif hukum positif di Indonesia.

\section{Pengaturan DP Nol Rupiah Dalam Kepemilikan Rumah}

Berdasarkan penafsiran gramatikal terhadap terminologiDown Payment (DP) Nol Rupiah, sesungghnya terdapat contracdictio in terminis. Terdapat kontradiksi dalam istilah atau terminologi itu sendiri.Dengan terminologi Down Payment, berarti harus ada uang muka, jadi tidak mungkin nol. Dengan terminologi DP Nol Rupiah berarti adalah tanpa DP.

Pemahaman DP Nol Rupiah yang dijanjikan atau yang merupakan program kerja Gubernur DKI Jakarta saat ini adalah terkait dengan mekanisme pembiayaan, jadi sesungguhnya tidak berarti DP-nya nol. DP tersebut tetap ada tetapi disubsidi atau ditalangi oleh pemerintah.Sebagaimana dikutif Liputan 6.Com,

rumah tangga termasuk perorangan, baik yang berpenghasilan tetap maupun tidak tetap, belum memiliki satuan rumah susun sederhana, belum pernah menerima subsidi satuan rumah susun sederhana dengan berpenghasilan sampai dengan Rp. 4.500.000,per bulan. 
bahwa pada tanggal 6 Mei 2017, Anis Baswedan, Gubernur terpilih DKI Jakarta mengemukakan bahwa program NP Nol Rupiah tidak dapat diibaratkan seperti pembelian sepeda motor pada umumnya.Ini lebih kepada program pembiayaan.Program DP Nol Rupiah merupakan kredit murah berbasis tabungan bagi masyarakat berpenghasilan menengah ke bawah. Program ini mengganti DP yang cukup tinggi dengan persyaratan lain untuk memastikan pembayaran kredit yang dapat dipenuhi warga.

Secara hukum, pada kesempatan ini tidak akan dibahas tentang kemukngkinan terlaksnanya atau tidak, DP Nol Rupiah dalam kepemilikan rumah bagi warga di DKI Jakarta melainkan bagaimana pengaturannya dalam hukum positif di Indonesia. Pemngertian hukum positif adalah hukum yang berlaku saat ini atau ius constitutum untuk membedakan ketentuan hukum yang akan berlaku di masa yang akan datang (ius constituendum) atau hukum yang dicita-citakan. Pemahaman tentang hukum psoitif tidak saja hukum dalam arti yang terutlis dalam bentuk undangundang formal atau undang undang dalam arti sempit melainkan segala ketentuan hukum yang terdapat dalam peraturan perundang-undangan (undang undang dalam arti materil atau dalam pengertian luas) sesuai dengan UU No. 12 Tahun 2011 tentang Peraturan Perundang Undangan, termasuk didalamnya hukum kebiasaan/adat sebagai sumber hukum formal dalam hukum positif di Indonesia.

\section{Down Payment Nol Rupiah Pada Umumnya}

Dengan memperhatikan Down Payment Nol Rupiah dalam pembelian rumah, maka yang dimaksudkan sesungguhnya adalah pembelian rumah melalui Kredit Pemilikan Rumah (KPR) dengan Down Payment-nya adalah Nol Rupiah. Dengan kata lain, KPR tanpa Down Payment.

Ketentuan umum tentang jual beli, termasuk jual beli rumah adalah buku III KUPerdata tentang Perikatan (van verbintennis), khususnya Pasal 1457 s/d Pasal 1540 KUHPerdata. Menurut undang-undang, juala beli adalah suatu persetujuan dengan mana pihak yang satu mengikatkan dirinya untuk menyerahkan suatu kebendaan dan pihak yang lain untuk membayar harga yang telah diperjanjikan. ${ }^{6}$ Menurut Pasal 1458 KUHPerdata, perjanjian jual beli adalah perjanjian termasuk perjanjian konsensual, yang artinya perjanjian jual beli sudah sah dan mengikat sesaat setelah para pihak mencapai konsensus atau sepakat mengenai halhal yang pokok dalam perjanjian. ${ }^{7}$ Tidak dibutuhkan syarat lain.Mengacu kepada kedua ketentuan hukum tersebut diatas, maka sesungguhnya pembelian rumah dengan DP Nol Rupiah adalah sah menurut hukum. Pembelian tidak dalam bentuk dan melalui lembaga pembiayaan.

Termilonologi DP Nol Rupiah dalam jual beli dalam praktiknya adalah jual beli dengan angsuran atau mencicil.Pembayaran atau angsuran pertama diangap sebagai down payment atau uang muka. Jual beli angsuran adalah perjanjian jual beli dengan mana pembayaran atau pelunasan harga dilakukan secara bertahap atau mencicil atau mengangsur dan pembayaran atau angsuran pertama dianggap sebagai DP atau uang muka dan seketika, hak milik atas barang yang dijual telah berpindah kepada pembeli hanya saja pelunasannya dilakukan secara mencicil atau mengangsur. Sekalipun jual beli secara angsuran atau jual beli dengan DP Nol Rupiah ini tidak diatur secara khusus dalam KUHPerdata melainkan merupakan species dari perjanjian jual beli, keabsahannya didasarkan kepada Pasal 1338 KUHPerdata ${ }^{8}$ yang dikenal dengan asas kebebasan berkontrak(partij autonomy). Maksudnya, kepada setiap anggota masyarakat diberikan kebebasan untuk membuat berbagai jenis perjanjian dalam bentuk dan berisi apa saja asalkan tidak bertentangan dengan undangundang, ketertiban umum dan kesusilaan baik dalam masyarakat.

Dalam praktiknya, tidak saja di daerah pedesaan, di kota-kota besar pun dapat ditemukan jual beli rumah dengan angsuran atau mencicil, yang pengikatannya dilakukan dalam bentuk Perjanjian Pengikatan Jual Beli (PPJB), dimana pada saat pelunasan baru

\footnotetext{
6 Pasal 1457 Kitab Undang Undang Hukum Perdata

7 Pasal 1458 KUHPerdata menentukan jual beli dianggap telah terjadi antara kedua belah pihak, seketika setelahnya orang-orang ini mencapai sepakat tentang kebendaan tersebut dan harganya, meskipun kebendaan itu belum diserahkan dan harganya belum dibayar.

8 Pasal 1338 KUHPerdata menentukan bahwa semua perjanjian yang dibuat secara sah berlaku sebagai undang-undang bagi mereka yang membuatnya.
} 
dilakukan Akta Jual Beli (AJB). Bagaimana termjin pembayaran hingga pelunasannya diatur dalam PPJB.Semuanya tergantung kepada kesepakatan atau konsesus para pihak.Jual beli sesuai Pasal 1458 adalah konsensual.

Dalam hukum adat juga diakui praktik pembelian rumah tanpa DP atau dalam bentuk jual beli angsuran. Karena sahnya jual beli menurut hukum adat adalah apabila dilakukan secara terang dan tunai.Terang dimaksudkan dibuat dihadapan pejabat yang berwenang dan ada saksi.Sedangkan tunai dimaksudkan adanya pembayaran, termasuk pembayaran dalam bentuk panjar atau uang muka baru kemudian pelunasanya dilakukan secara mencicil.

\section{Down Payment Nol Rupiah dalam Bentuk Kredit Pemilikan Rumah}

Permasalahan selanjutnya adalah bagaimana jika pembelian rumah melalui Kredit Pemilikan Rumah (KPR) apakah dimungkinkan dengan DP Nol Rupiah dan bagaimana pengaturannya dalam peraturan perundang-undangan di Indonesia.

Bertitik tolak dari sulitnya memiliki rumah karena harga yang mahal dan tidak terjangkau, maka sejak tahun 1974 telah diperkenalkan pembelian rumah dengan fasilitas pembiayaan atau Kredit Pemilikan Rumah (KPR) sebagai fasilitas pembiayaan yang diberikan lembaga pembankan atau lembaga keuangan bukan bank untuk membeli rumah. Melalui KPR, nasabah atau pembeli cukup membayar uang muka (DP) dan sisanya akan dilunasi oleh bank atau lembaga keuangan bukan bank lainnya. Fasilitas KPR memperbesar kemungkinan kelompok masyarakat untuk memiliki rumah.Dengan cicilan ringan setiap warga cukup membayar uang muka berdasarkan harga jual rumah.

Di lingkungan perbankan sendiri, pemberian KPR merupakan salah satu usaha bank dalam memberikan kredit kepada masyarakat, yang dalam hal ini dalam bentuk Kredit Pemilikan Rumah. Di lain pihak adalah juga bank dan lembaga keuangan bukan bank lainnya yang menawarkan Kredit Kepemilikan Kenderaan Bermotor (KKB). Mengingat KPR merupakan perwujudan dari usaha bank untuk memberikan kredit kepada masyarakat, maka pengaturannya tindak dan berlakulah UU Perbankan yang tersebut dalam UU No. 7 Tahun 1992 tentang Perbankan sebagaimana telah dirubah dan disempurnakan dengan UU No. 10 Tahun 1998.

Selain Undang Undang Perbankan, ketentuan operasional pemberian KPR bagi bank diature dalam Peraturan Bank Indonesia No. 18/16/PBI/2016 tentang Rasio Loan to Value untuk Kredit Properti, Rasio Financing to Value untuk Pembiayaan Properti dan Uang Muka Untuk Kredit atau Pembiayaan Kenderaan Bermotor tanggal 28 Agustus 2016, Lembaran Negara Republik Indonesia tahun 2016 Nomor 178, Tambahan Lembaran Negara No. 5924. Dengan Peraturan ini, Bank Indonesia sebagai bank sentral di Indonesia telah menetapkan Loan to Value (LtV) atau persentase sekitar $85 \%$ dari harga jual rumah.Artinya, calon pembeli property cukup menyiapkan uang muka (DP) minimal $19 \%$ untuk diserahkan pada saat akad jual beli.Dengan demikian, tidak dimungkinkan untuk DP Nol Rupiah.

Namun, khusus untuk program penyelenggaraan perumahan pemerintah, hal ini diatur dalam Pasal 17 yang menentukan bahwa kredit atau pembiayaan dalam rangka pelaksanaan perumahan Pemerintah Pusat dan/atau Pemerintah Daerah sebagaimana dimaksud dalam peraturan perundang-undangan yang berlaku, sepanjang didukung dengan dokumen yang menyatakan bahwa kredit atau pembiayaan tersebut merupakan program perumahan Pemerintah Pusat dan/ atau Pemerintah Daerah, dikecualikan dari ketentuan ini dengan tetap memperhatikan prinsip kehati-hatian dalam peraturan perundang-undnagan terkait yang berlaku.

Berdasarkan ketentuan dalam Pasal 17 PBI No. 18/16/PBI/2016 diatas, pengaturan DP minimal 15 $\%$ dapat dikesampingkan dalam kaitannya dengan pelaksanaan Perumahan Pemerintah Pusat dan/atau Pemerintah Daerah. Dalam arti harus ada jaminan dari Pemerintah Pusat dan/atau Pemerintah Daerah baru kemudian diatur skema pembayarannya. Jadi sesungguhnya tidak mudah dan harus tetap memperhatikan prinsip kehati-hatian (prudential) dan peraturan perundang-undanganterkait lainnya.Sampai dengan saat ini belaum ada aturan organik tentang hal ini sehingga butuh peraturan lebih lanjut. 
Dalam rangka memenuhi kebutuhan Masyarakat Berpenghasilan Rendah (MBR) dalam memiliki rumah layak huni, pemerintah gencar mempromosikan program sejuta rumah. Menurut Peraturan Gubernur DKI Jakarta No. 27 Tahun 2009 tentang Pembangunan Rumah Susun Sederhana, MBR dirumuskan sebagai kelompok sasaran keluarga/rumah tangga termasuk perorangan, baik yang berpenghasilan tetap maupun tidak tetap, belum memiliki satuan rumah susun sederhana, belum pernah menerima subsidi satuan rumah susun sederhana dengan berpenghasilan sampai dengan Rp. 4.500.000,- per bulan. Melalui Peraturan Menteri Perumahan Rakyat No. 10 Tahun 2012 tentang Penyelenggaraan Perumahan dan Kawasan Permukiman Dengan Hunian Berimbang yang telah mulai berlaku sejak 7 Juni 2012, para pengembang wajib membangun permukiman dengan komposisi 3 : $2: 1$ (tiga berbanding dua berbanding satu), yaitu tiga atau lebih sumah sederhana berbanding dua rumah menengah berbnding satu rumah mewah kecuali seluruhnya diperuntukkan bagi rumah sederhana dan/atau rumah susun umum. Pemerintah melalui Perumahan Nasional Perumnas ${ }^{9}$ memprogramkan proyek sejuta rumah dan seribu menara.Sejak didirikan tahun 1974, tidak kurang dari 500.000 unit rumah sudah dibangun Perum Perumnas di seluruh propinsi dengan tipe Rumah Sederhana Sehat (RSh), Rumah Sederhana (RS) dan Rumah Menengah (RM). Pemerintah juga mengembangkan proyek seribu menara dengan membangun hunian vertical (rumah susun) berupa Rumah Susun Sederhana Sewa (Rusunawa) ${ }^{10}$ dan Rumah Sususn Sederhana Milik (Rusunami).

Selain pembelian secara tunai, masyarakat juga bisa memiliki rumah melalui program kredit rumah murah atau dikenal dengan KPR FLPP (Fasilitas Likuiditas Pembiayaan Perumahan).Dengan KPR rumah murah seperti ini, masyarakat bisa mendapat keleluasaan dalam mengasur rumah selama maksimum 20 tahun dengan suku bunga tetap sepanjang masa kredit. Dalam hal ini harus ada kerjasama dengan

9 Perumahan Umum Nasional (Perumnas) adalah Badan Usaha Milik Negara (BUMN) yang berbentuk Perusahaan Umum (Perum) dimana keseluruhan sahamnya dimiliki oleh Pemerintah.

10 Rumah Susun Sederhana Sewa (Rusunawa) adalah rumah susun sederhana yang disewakan kepada masyarakat perkotaan yang tidak mampu untuk membeli rumah atau yang ingin tinggal untuk sementara waktu misalnya para mahasiswa, pekerja temporer dan lainya.
Pemerintah Pusat cq. Kementerian Pekerjaan Umum dan Perumahan Rakyat (PUPR) karena dananya akan mempergunakan Anggaran Pendapatan dan Belanja Negara (APBN) sebagaimana diatur dalam Pasal 126 ayat (4) UU No. 1 Tahun 2011 tentang Perumahan dan Kawasan Permukiman yang memerintahkan untuk untuk membuat Peraturan Pemerintah tentang kemudahan dan/atau bantuan pembiayaan. Salah satu pertimbangan Peraturan Menteri Perumahan Rakyat Nomor 27 Tahun 2012 tentang Pengadaan Perumahan melalui Kredit/Pembiayaan Pemilikan Rumah Sejahtera dengan Dukungan Fasilitasi Likuidasi Pembiayaan Perumahan adalah bahwa penyediaan dana murah jangka panjang sebagaimana dimaksud dalam Pasal 126 ayat (3) huruf (c) UU No. 1 Tahun 2011 berupa bantuan pembiayaan pemilikan rumah dengan suku bunga yang tetap dan terjangkau selama masa pembiayaan dalam rangka meningkatkan kemampuan daya beli masyaraiat berpenghasilan rendah untuk memperoleh rumah.

\section{Kesimpulan}

Pengaturan tentang Down Payment (DP) Nol Rupiah dalam kaitannya dengan kepemilikan rumah diatur dalam KUHPerdata, khususnya buku III KUHPerdata dan sejumlah peraturan perundangundangan lainnya yang tersebut dalam UU No. 1 Tahun 2011 tentang Perumahan dan Kawasan Permukiman dan sejumlah aturan organik lainnya melalui Keputusan Menteri dan Gubernur Bank Indonesia, termasuk hukum adat sebagai salah satu sumber hukum positif yang menentukan sahnya jual beli tanah dan/atau rumah.

Sesuai ketentuan hukum positif yang berlaku, maka kepemilikan atau perolehan rumah dengan DP Nol Rupiah atau tanpa Down Payment dimungkinkan dan sah menurut hukum berdasarkan kesepakatan para pihak yang dalam praktiknya banyak dilakukan secara orang perorangan, namun bila jual beli rumah tersebut dilakukan melalui badan usaha, maka sesuai aturan yang berlaku adanya uang muka atau down payment tersebut merupakan suatu keharusan 
Down Payment Nol Rupiah dalam Kepemilikan Rumah Menurut Hukum Positif di Indonesia

\section{Saran}

Sudah saatnya pemerintah merumuskan kebijakan sebagai realisasi dari hak dan jaminan pemerintah atas penyediaan rumah yang layak dan sehat yang dapat terjangkau oleh seluruh lapisan masyarakat.

\section{DAFTAR PUTAKA}

Badan Pembinaan Hukum Nasional Kementerian Hukum dan HAM RI, Analisis Dan Evaluasi Pera- turan Perundang Undangan Tentang Perumahan Rakyat, Jakarta 2015.

Muhamad Abdulkadir, Hukum Perjanjian, PT. Alumni, Bandung, 1986.

Subekti R dan R. Tjitrosudibio, Kitab Undang Un- dang Hukum Perdata, Pradnya Paramita, Jakarta, 1986.

Undang Undang Nomor 1 Tahun 2011 tentang Peru- mahan dan Kawasan Permukiman

Undang Undang Nomor 10 Tahun 1998 tentang Perubahan UU No. 7 Tahun 1992 tentang Per- bankan

Peraturan Bank Indonesia No. 18/16/PBI/2016 tentang Rasio Loan to Value untuk Kredit Properti, Rasio Financing to Value untuk Pembiayaan Properti dan Uang Muka Untuk Kredit atau Pembiayaan Kenderaan Bermotor 